Esther Rinke*, Cristina Flores and Pilar Barbosa

\title{
Null objects in the spontaneous speech of monolingual and bilingual speakers of European Portuguese
}

DOI 10.1515/probus-2017-0004

\begin{abstract}
This paper investigates object omissions in the spontaneous production of European Portuguese by second generation Portuguese-German bilingual speakers and compares them to first generation migrants, and two age-matched groups of monolingual speakers. The results show that bilingual speakers as well as the younger generation of monolinguals show a higher number of null objects in their speech than the two older generations. This may reflect an inter-generational development that favours null objects, which is independent of language contact. The analysis of the syntactic and semantic conditions determining the occurrence of null objects in the speech of the different groups reveals that the semantic properties of the null objects realized by the bilinguals, particularly the higher rates of animate and nonpropositional null objects, show that they extend the semantic-pragmatic conditions of null object realization along the referentiality hierarchy proposed by Cyrino, Duarte and Kato (2000). The bilingual speakers may reflect a language-internal pathway that appears to resemble a diachronic change observed in BP.
\end{abstract}

\section{Key words}


null objects, European Portuguese, German, referentiality hierarchy, bilingual speakers' competence, spontaneous speech, animacy effects 


\section{Introduction}

The present study investigates the distribution of null objects in the spontaneous speech of different speakers of European Portuguese (EP). The speech of adult PortugueseGerman bilingual speakers, so called heritage speakers (HSs) of EP is compared to three other groups: an older group of first generation migrants, who are late learners of German, and two age-matched groups of older and younger monolingual speakers. The comparison of different generations of speakers, on the one hand, may help to detect change in apparent time (cf. Labov 1963). On the other hand, the systematic comparison of the spontaneous speech of monolingual and bilingual speakers allows to study possible effects of language contact.

Even though we compare spontaneous production of different groups of speakers, our main interest lies in the group of heritage bilinguals. These are speakers who grow up in a migration context (Germany, in the present case) with two languages in their daily life, the heritage language (here EP), spoken within the family, and the language of the dominant environment, commonly also the school language. The development of the heritage language has attracted growing attention within the scientific community interested in bilingualism, for several reasons: educational (see the recent handbook edited by Trifonas \& Aravossitas 2017), socio-political and (psycho)linguistic. From a linguistic perspective, the interest in studying heritage languages comes from the fact that heritage speakers have contact with their heritage language from birth on, so that it can be classified as a native language (Rothman \& Treffers-Daller 2014). However, exposure to this language tends to decrease with aging, while the majority language becomes the dominant and preferred one. Consequently, the heritage language is a first language that is acquired under reduced input conditions and in the presence of a stronger language. As an outcome of these specific acquisition conditions, heritage speakers often display differences in competence and performance when compared to monolingual speakers. This has led several scholars to describe the development of 
heritage languages as process of incomplete acquisition (Montrul 2008), implying an acquisition deficit that somehow questions the acknowledged predisposition of the human language faculty for acquiring several native languages simultaneously (as defended, for instance, by Meisel 2001). The ongoing debate on the (in)appropriateness of this concept (see the discussion in Kupisch \& Rothman 2016) indicates that the development of heritage grammars is still not fully understood. Special caution is required in the interpretation of outcome differences between heritage speakers and other speaker groups, which are often and hastily explained either as failure in acquiring a linguistic structure or as an effect of cross-linguistic influence. The present paper addresses possible outcome differences between heritage speakers and other speaker groups with respect to object omission. It investigates i) whether the production of null object structures in the speech of these bilingual migrants differs quantitatively and/or qualitatively from the production of three other groups; and if so ii) how possible divergences can be best accounted for.

Null objects are a frequent and regular phenomenon in Portuguese, in EP (cf. ex. 1) as well as in Brazilian Portuguese (BP).

(1)

EP Comprei aquele livro e dei $[-] \grave{a}$ Maria.
bought that book and gave to.the Maria
'I bought that book and gave it to Mary.'

(Costa, Lobo and Silva 2009: 145)

The analysis of these constructions has shown that definite and anaphoric null objects have to be distinguished from other types of object omissions, e.g. VP-ellipsis and incorporated arguments (e.g. so-called default and shadow arguments). VP-ellipsis and null objects are particularly hard to differentiate and, therefore, existing corpus studies have failed to clearly distinguish them. Syntactically, null objects in EP have originally 
been analysed as variables bound by an empty operator and are associated to a sentence external discourse topic (cf. Raposo 1986). For BP, it has been proposed that the null objects represent an empty pronominal category (pro) (Farrell 1990; Kato 1993). In a later paper, Kato and Raposo (2005) propose a unified analysis of the null objects for $\mathrm{EP}$ and $\mathrm{BP}$ in terms of an empty determiner.

While semantic features such as 'animacy', 'specificity' and 'definiteness' have been shown to be important constraints of null / overt pronoun realization in BP (Cyrino, Duarte and Kato 2000), only a recent variationist study conducted by Schwenter (2014) has suggested that these semantic features are relevant for the encoding of direct object referents in EP in a similar way, even though both dialects differ with respect to the pronoun type (strong pronoun in BP, clitic in EP). This means that also in EP animacy effects may be relevant for pronoun omission / realization, a fact not yet addressed from a theoretical perspective. In addition, the comparison to BP may be revealing, since it has been shown (cf. Cyrino et al. 2000) that the null object in BP has diachronically extended its distribution along a referential hierarchy, the most referential arguments (+human, + spec, $1^{\text {st }} / 2^{\text {nd }}$ person) being the most resistant to realization as null elements. What is particularly relevant for the present study is that the diachronic evolution of the null object construction in BP may illustrate a universal diachronic pathway that may also explain the extension of null objects in the speech of bilingual populations as, in our case, heritage speakers of EP.

In addition, or as an alternative to language internal universal pathways, also language contact is commonly assumed to explain differences between monolingual and bilingual speech (Silva-Corvalán 1994). Although German does not allow for definite null objects, it has a construction that is superficially similar, the so-called topic drop structure (cf. Flores 2012; Trutkowski 2016). It has been proposed that superficial similarities between missing object constructions may play a central role when two languages are in contact. An increase in object omissions is reported for bilingual 
populations both in the literature on language contact (e.g. Camacho, Paredes and Sánchez 1997; Franco and Landa 2003; Sánchez 1999) as well as in early stages of bilingual language acquisition (e.g. Müller and Hulk 2001; Pirvulescu et al. 2014).

Taking into account that syntactic and semantic features constrain the occurrence of object omissions, the present analysis will focus on the following aspects: (i) the type of object omissions (e.g. VP-ellipsis, default and shadow arguments, genuine null objects $^{1}$; (ii) the syntactic constructions in which the null objects occur, specifically their distribution in syntactic islands or in sentence-initial position, resembling German topic drop and iii) the semantic-pragmatic factors governing the distribution of null objects, particularly the features [+ / - propositional $]$ and [+ / - animate]. Differences between the speaker groups concerning the syntactic factors would either indicate that the bilingual population did not fully acquire this construction or that they have developed a different kind of null object construction, for instance one that is similar to German topic drop. The consideration of the semantic factors may reveal whether the bilingual speakers have extended the semantic properties of null objects along a referential scale as proposed by Kato, Duarte and Cyrino (2000) for BP.

The paper is structured as follows: In section 2 we describe the syntactic as well as semantic/pragmatic conditions under which null objects occur in EP. We will show how genuine null object constructions differ from other types of object omissions (and German topic drop). We will also discuss how the distribution of null objects relates to the referentiality hierarchy and how this relation can explain diachronic developments in BP. On this basis, section 3 introduces the different speaker groups and the methodology of data analysis and develops more concrete research questions and hypotheses. In section 4 , the results of our corpus study are presented. We give an

\footnotetext{
${ }^{1}$ The distinction between these types of object omissions implies coding for specificity and definiteness. Only [+ definite] and [+specific] objects are coded as null objects.
} 
overview on the realization of null objects in the different subcorpora and consider structural aspects such as their occurrence in islands, the position of the clitic and the existence of strong pronouns. We further consider semantic and referential aspects such as the distribution of propositional (null) objects and animacy. Section 5 summarizes and concludes.

\section{Object omissions}

\subsection{Null objects in Portuguese}

\subsubsection{Distinguishing different types of object omissions}

One aspect that characterizes the null object construction exemplified in (1) is that the missing argument is definite. This point is important, given that there are languages that allow for bare indefinite objects to drop, and yet disallow definite or specific null objects. This is the case of Spanish (Campos 1986) and Greek (Giannakidou and Merchant 1997). Therefore, the null object construction should be distinguished from other cases of unrealized objects.

One such case features object omissions with particular verbs, such as 'smoke', as in 'John smokes', or 'eat', as in 'John already ate'. These sentences have been referred to in the literature as 'unspecified object sentences' (Raposo 1986: 376) due to the fact that the understood object is interpreted as indefinite and non-specific, more precisely as an indefinite representative of the class of objects that may be acted upon by the event described by the verb. Unspecified object sentences have semantic and pragmatic properties that are very different from those of the null object construction. As already mentioned before, null objects are definite and specific, whereas objects in unspecified object sentences are non-specific. While the null object is highly dependent on pragmatic context, unspecified objects do not. In our data analysis, we have differentiated between genuine null objects and unspecified objects. 
Portuguese has yet another type of anaphoric construction with null elements that has to be separated from the null object construction. This construction, called VP ellipsis, is illustrated in the following example (Raposo 1986: 376f.):

(2) Question: A empregada colocou os livros na estante? the maid put the books on.the shelf 'Did the maid put the books on the shelf?'

Answer: $\quad$ Sim, colocou. yes, put 'Yes, she did.'

In example (2), the two internal arguments (os livros; na estante) are missing, which suggests that what is being elided is the whole VP. Since EP is a verb raising language, omitting the VP after V has raised out of the VP will leave V stranded: [ тр Colocou [ es livres astante ]]

VP ellipsis occurs not only in the context of question-answer pairs but also in contexts of coordination like the one illustrated in (4).

(4) João descascou a banana, mas Pedro não descascou

John peeled the banana but Pedro not peeled

'John peeled the banana but Pedro didn't.'

(Matos 1992, cit. apud Cyrino 2000)

Even though V-stranding VP ellipsis is unattested in the other Romance languages besides EP, it has been described in a variety of non-Romance languages, such as 
Finnish (Holmberg 2001), Hebrew (Doron 1999) and Russian (Gribanova 2013), among others. In many cases, the output of VP ellipsis is virtually indistinguishable on the surface from that of a structure with a null object. One diagnostic that has been proposed in the literature to distinguish the two constructions (Doron 1999; Raposo 1986) is that VP ellipsis only applies if an antecedent VP is present in the preceding discourse. A null object, in contrast, may be licensed when the antecedent is situational ${ }^{2}$. In our corpus analysis, we distinguished between cases of VP-ellipsis and null object constructions on the basis of these criteria.

\subsubsection{Syntactic structure of null object constructions in EP}

Based on Huang's (1984) work on Chinese, Raposo (1986) analyzes null objects on a par with topicalized objects, the difference being that, in the former case, the topicalized element may be null. Null objects in EP must refer to a salient discourse topic ${ }^{3}$.

Raposo (1986: 379) attributes the following structure to a null object construction:

$$
\begin{array}{r}
{\left[\mathrm{Top} e_{i}\right]\left[\mathrm{s}, \mathrm{OP}_{\mathrm{j}}\left[\mathrm{s} \text { a Joana viu } e c_{j} \text { na } \mathrm{TV} \text { ontem }\right]\right]} \\
\text { the Jane saw in-the TV yesterday }
\end{array}
$$

'Jane saw it/him/them on TV yesterday.'

According to this analysis, null objects are variables bound by an A'-topicoperator. What distinguishes languages that allow null objects of this kind from those

\footnotetext{
${ }^{2}$ Another diagnostic employs the different behavior of V-stranding, VP ellipsis and missing objects in islands. Ellipsis can target a $v \mathrm{P}$ embedded in an island. According to some authors (Raposo 1986, Gribanova 2013), in the same environment, object drop is deviant. Our results show that null objects do indeed occur in islands in spoken EP, so this diagnostic is not tenable.

${ }^{3}$ The presence of a linguistic antecedent is not strictly required. The content of the null object may be pragmatically retrieved, i.e., it may be inferred from the pragmatic environment.
} 
that do not is that the former allow zero topics to bind variables.

Raposo (1986) argues in favor of this analysis on the basis of locality effects. According to him, the null object in European Portuguese is excluded from islands, such as complex noun phrases (Complex-NP-Constraint; 6a.) and adverbial adjunct clauses

a. $\quad * O$ rapaz que trouxe

$\mathrm{e}_{\mathrm{i}}$ mesmo agora $\quad d a$

pastelaria era

the boy that brought right now from.the pastry shop was o teu afilhado.

the your godson

(Raposo 1986: 382)

b. *O pirata partiu para as Caraíbas depois de ter guardado the pirate left for the Caribbean after of to.have guarded $e_{i}$ cuidadosamente no cofre. carefully in the safe.

(Raposo 1986: 382)

In his more recent work, Raposo (2004: 47) recognizes that his original acceptability judgements concerning examples like (6a) and (6b) were too strict and that some of the sentences showing null objects in islands were acceptable in EP to some degree as well. He proposes an analysis of the null object in EP in terms of an empty determiner embedding pro and points out the parallelism of the respective structures with topicalization structures. In clitic left dislocation (CLLD) structures such as (7) below, the determiner embeds and identifies ${ }^{4}$ the content of an empty pronominal

4 Raposo (2004) assumes that the reference of the complex [o...pro] is established via a rule of predication (Chomsky 1977), which attributes the referential content of the linguistic or contextual topic to this entity. 
element (pro) and is moved to preverbal position. The topic may be realized or may be implicit. This shows example (7) from Kato and Raposo (2005).

(7) (esse livro), eu só o encontrei [DP $\underline{t} \underline{\text { pro }}]$ na FNAC.

Kato and Raposo (2005) attribute a parallel structure to null object constructions (8), the only difference being that the determiner is phonologically empty in (8). According to the authors, the empty determiner lacks features for gender and number and can therefore not contribute to the identification of pro. For this reason, pro is moved to a position close to its antecedent DP were it can be directly identified. According to Kato and Raposo (2005), the relevant functional category is FP (cf. Raposo 2004; Raposo and Uriagereka 1996; Uriagereka 1995).

(8) (esse livro) [FP $\underline{\operatorname{pro}}+\mathrm{F}$ [TP eu só encontrei [DP D $\underline{t}$ ] na FNAC]]

\subsection{Referential properties determining the distribution of null objects}

The way in which the distribution of null objects in EP is determined by referential features is hinted at though not fully developed in the theoretical literature on the topic. Costa and Duarte (2003: 256) claim that some speakers of EP, like speakers of BP in general, do not accept animate null objects in strong islands (cf. Bianchi and Figueiredo 1994 for BP). 
(9) A E este carro?

and this car?

B ?O Zé ficou nervoso porque o Pedro comprou ec.

the Zé became nervous because the Pedro bought

(10) A E a Maria?

and the Mary

B *O Zé ficou nervoso porque o Pedro beijou ec.

the Zé became nervous because the Pedro kissed_

(Costa and Duarte 2003: 256)

According to Duarte and Costa (2014), an animacy effect also arises in EP when the antecedent and the null object occur in one and the same sentence. According to the authors, the omission of an animate null object as in (11a) and (12a) determines the marginality or ungrammaticality of the examples for most speakers of EP.

(11) a. *Quando encontro o Pedro, beijo [ec] com ternura.

when find the Pedro kiss tenderly

'When I find Pedro I kiss him tenderly.'

b. Quando encontro uma gralha, corrijo [ec] imediatamente.

when find a flaw correct immediately

'When I find a flaw, I correct it immediately.'

(Duarte and Costa 2014: 2345)

5 Note that the examples (11a) and (11b) differ with respect to the definiteness of the objects. In our view this might have an influence on the judgments. However, in (12a) and (12b) the same effect arises 
(12) a. ??Se achas que a Maria é uma chata, eu não convido [-] para a festa. if (you) find that the Mary is a drag I not invite [-] for the party 'If you find that Mary is a drag, I will not invite her for the party.'

b. Se achas que esse livro é chato, eu não compro [-] para a María. if (you) find that this book is boring I not buy [-] for the Mary 'If you find that this book is boring, I will not buy it for Mary.'

(Duarte and Costa 2014: 2345)

In the two cases reported, inanimate null objects are preferred over animate ones. According to Costa and Duarte (2003: 256) there is no animacy restriction in weak islands.

(13) A: E este carro?

and this car

'What about this car?'

B: O Zé quer saber quem comprou ec.

the Zé wants know who bought ec

'Zé wants to know who bought (it)' 
(14) A: E a Maria?

and the Maria

'What about Maria?'

B: $\quad$ Z Zé quer saber quem beijou $e c$.

the Zé wants know who kissed ec

'Zé wants to know who kissed (her).'

For Duarte and Costa (2014) there is also no animacy restriction if the antecedent is exterior to the sentence or situationally given:

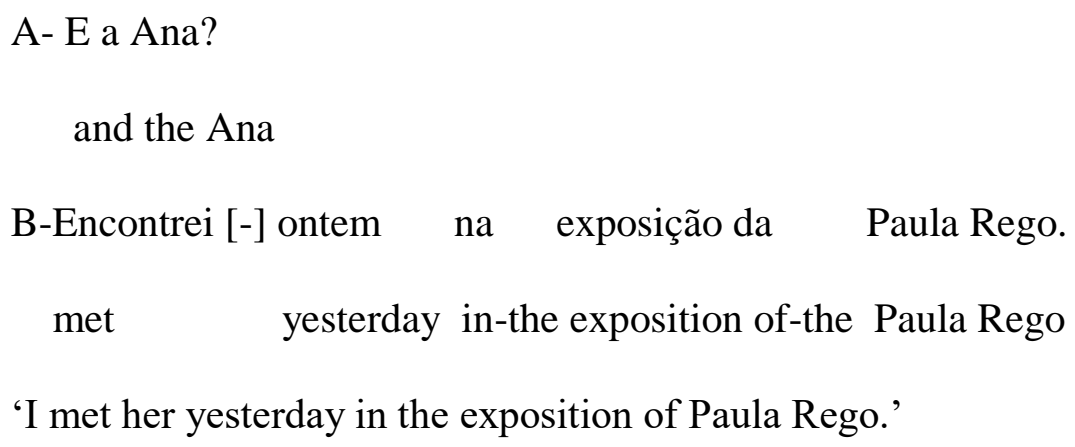

(Duarte and Costa 2014: 2345)

In spite of these claims, a recent experimental study on the acceptance of null and overt objects by Castro (2016) shows that animacy restrictions do indeed play a role for monolingual native speakers of EP — independently of the syntactic environment (simple clause or islands). Moreover, Schwenter (2014) carries out a detailed multivariate quantitative analysis of naturally occurring data in comparable samples in $\mathrm{EP}$ and $\mathrm{BP}$ and shows that there is a clear division of labour between pronouns $-\mathrm{BP}$ tonic pronouns and EP clitics — and null objects in both varieties. The most significant contrast revealed by the multivariate analysis is not so much the differences between EP and $\mathrm{BP}$, but rather the opposition between the zero marking of anaphoric direct objects and their overt realization as pronouns. In both varieties, inanimate direct object 
referents are significantly more likely to be null while definite human anaphoric direct object referents are more likely to be pronouns. Schwenter concludes that the overall grammatical marking strategy in both varieties is to employ more marking on nonprototypical (human and specific/definite) direct objects, and less marking on prototypical (inanimate and non-specific/indefinite) direct objects, with null realization being the "less" option in both BP and EP for anaphoric direct objects. Schwenter (2014) goes on to observe that this kind of opposition is precisely what is found in languages that have differential object marking (DOM), such as Spanish or Romanian. In DOM languages, the lack of marking on a direct object contrasts with an overt marker that typically occurs with animate/definite/specific direct object referents — a preposition in the case of Spanish/Romanian or more clear morphological case marking in other unrelated languages such as Hindi or Turkish. In view of the correlation found between overt marking and animacy/definiteness/specificity, Schwenter proposes that the patterns of anaphoric direct object marking in BP and EP are in reality a type of DOM: whether they can be considered a "true" case of DOM is "more a definitional issue than a substantive one" (Schwenter 2014: 257).

The literature on BP has long recognized the differential role played by animacy/definiteness/specificity in the distribution of null versus overt anaphoric direct objects. This was first pointed out by Duarte (1986) and further described in Cyrino (1997). Moreover, Cyrino et al. (2000) show that there is a diachronic development concerning the animacy of null objects: null objects referring to non-human and nonspecific antecedents are diachronically the first to be empty whereas null objects with [+human] and [+specific] antecedents are more resistant to be null. In contemporary BP, [-human] or propositional objects are almost categorically null. The authors argue that the referential status of an object in the referential hierarchy ${ }^{6}$ given in (17) determines

6 There are many authors that propose that semantic features determine the referentiality of noun phrases and that they may be organized along a referential scale (e.g. Aissen 2003, Leonetti 2008, Silverstein 
the likelihood of its realization as a null element or a realized pronoun. The more referential an object is (the more characterized by the features on the right of the scale) the more likely is it that this element is realized as a non-empty pronoun.

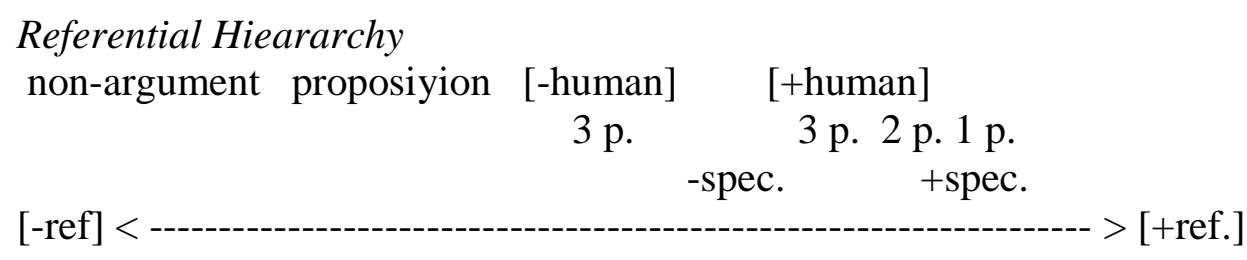

This explains, why null objects show a tendency to be characterized as $3^{\text {rd }}$ person and [non-human]. According to the authors, this hierarchy is implicational: a language that has a null variant at a specific point in the scale implies that it has also a null variant for less referential objects to its left. Diachronically, the extension of null objects proceeds on the referential scale from left to right, as the authors show on the basis of data from BP (Cyrino et al. 2000).

In section 3, we will relate the discussion of the syntactic and semantic properties of null objects to the research questions mentioned in the introduction. We will develop some subquestions and hypotheses on the basis of what has been said so far.

\subsection{German topic drop}

Topic drop in German refers to a construction in which a sentence-initial topic constituent can remain phonologically empty. This constituent can be the subject or an accusative object $(18 \mathrm{~b}, \mathrm{c})$. It is generally assumed that Datives, Genitives and PP constituents cannot be dropped. However, dropping of VP-constituents is also possible (19). 
(18) a. Ich hab' ihn schon gesehen

I-NOM have him-ACC already seen

'I saw him already'

b. [ ] hab' ihn schon gesehen [ ] = NOM

c. [] hab' ich schon gesehen [ ] = ACC

(examples from Bayer et al. 2001: 490)

(19) Speaker A: Du musst dein Bett machen

you must your bed make

'You have to make your bed'

Speaker B: [ ] habe ich schon!

have I already

'I have already' (examples from Bayer et al. 2001: 490)

Given the restrictions on topic drop, it is generally analysed as "pronoun zap" (Ross 1982, Huang 1984), a construction in which a pronoun is deleted after having been moved to the sentence-initial position (SpecCP).

As pointed out by Flores (2012), German topic drop and Portuguese null objects occur in the same pragmatic contexts, namely when a topic (in 20 a particular movie) is given in the previous context.

(20) a. Pt. A Joana viu $\varnothing$ na TV ontem. the Joana saw on TV yesterday 'Joana saw it on TV yesterday.' (Raposo, 1986) 
(21) a. Ger. Ø Hat Joana gestern im Fernsehn gesehen.

has Joana yesterday on television seen

'Joana saw it on TV yesterday.'

b. [TOP $\left.t_{i}\right]\left[\right.$ hat Joana gestern im Fernsehn $t_{i}$ gesehen]

(Flores 2012: 3)

If the empty constituent is the direct object as in (18c), German topic drop is structurally similar to the EP null object construction in the sense that it includes a silent topic and an empty pronoun in the canonical object position. However, as Flores (2012) points out, the similarity is only superficial. Given the fact that German is a verb second language, the finite verb necessarily occupies the second position after the silent topic. Because German is a non-null subject language, the subject has to occur post-verbally (cf. ex. 21). Hence, the German construction differs from the Portuguese null object construction in the following ways: a) the zero-topic can either be a subject or an object constituent in German; b) the topic occupies the sentence initial position (pre-field, Spec $\mathrm{CP}$ ) in front of the finite verb (in C) leading to verb-initial sentences and c) if the zero topic is the object, the subject occupies the post-verbal position (19c); if the zero topic refers to the subject, the object cannot be omitted (19b). For the present study it is important to stress that there are no animacy restrictions related to German topic drop.

\section{Corpus study}

\subsection{Speakers and methodology}

This study is based on oral interviews of four different groups of speakers of European Portuguese: 1) a group of eight first generation migrants [G1_bil], who migrated to Hamburg/Germany as adults in the 1960s / 1970s (mean age $=59.88 ; \mathrm{SD}=6.94) ; 2$ ) eight second generation Lusophone immigrants [G2_bil], who were born and raised in Hamburg/Germany (mean age $=27.38 ; \mathrm{SD}=4.03$ ); and two groups of Portuguese 
monolingual speakers without migration background who match the migrants' profile in age and education: 3) 8 older and low-educated speakers [G1_mon] in the age span of 54 to 74 years (mean age $=64.25 ; \mathrm{SD}=5.92)$ and 4 ) 8 younger speakers [G2_mon] with high school or university degree who are between 18 and 32 years old (mean age $=25.25 ; \mathrm{SD}=5.39)$.

The second generation immigrants constitute our target research group. They are heritage speakers of EP, who were exposed to their heritage language since birth and used it mainly in interaction with their parents and other Portuguese migrants living in Hamburg. Exposure to German, the majority language, increased when the speakers entered kindergarten (around age three) and became stronger after entering elementary school. Although being fully fluent in both languages, all heritage speakers claimed to feel more comfortable in speaking German, which is typical for second-generation immigrants.

All speakers were interviewed individually for approximately one hour, on topics related to the interviewee's life experience. In the case of the heritage speakers, the interviews were conducted exclusively in Portuguese but the participants used German words sporadically (e.g. in cases of lexical retrieval problems). The oral interviews were transcribed and all transitive contexts (a total of 10.880 tokens) were coded for the type of object realization. The mean distribution of coded tokens is similar in the four groups (2672 tokens in G1_BIL, 2627 in G2_BIL, 2802 in G1_MON and 2779 G2_MON), revealing comparable datasets.

Our analysis will focus on the following coding variables:

I Proportion of null object constructions in the corpora (differentiating object realizations from object omissions, as well as genuine null object constructions from other types of object omissions, cf. 2.1.1);

II Structural aspects of null objects with the following coding variables (cf. 2.1.2):

a) occurrence of null objects in islands; 
b) null objects in verb-initial sentences with post-verbal subjects (parallel to German topic drop);

III Semantic aspects of object realization (cf. 2.2):

e) Propositional vs. non-propositional null objects/clitics

f) Animacy: $1 \mathrm{st} / 2^{\text {nd }}$ person vs. $3^{\text {rd }}$ person; animate / inanimate referents.

For the statistical analysis, ANOVA and chi-squared tests were performed in the statistical program $\mathrm{R}$.

\subsection{Hypotheses}

The discussion in section 2 has revealed a number of important points that are taken into consideration in the data analysis. First, it is important to distinguish between different types of object omissions, although this is not always easy. We differentiate between implicit (indefinite) arguments, VP-deletion and "genuine" null object constructions, which are necessarily anaphoric definite $3^{\text {rd }}$ person objects. Our further analysis will focus on the latter. The main interest of this study lies in potential qualitative and quantitative differences between the group of bilingual speakers and the other groups.

Taking the previous considerations together, we will pursue the following hypotheses.

Hypothesis 1 - General acquisition deficit: A first hypothesis is that the bilingual speakers haven't successfully acquired the null object construction, showing deviant knowledge compared to monolingual speakers. This general acquisition deficit may be visible in an absence or an overall very low number of null objects.

Hypothesis 2 -Cross-linguistic influence (CLI): The second hypothesis is that bilingual speakers may show a higher number of null objects in their speech than the other groups, but only in specific syntactic contexts, namely in verb-initial sentences 
with post-verbal subjects. This would be related to cross-linguistic influence in the sense that the bilingual speakers would produce a higher number of null object constructions that are superficially similar to German topic drop.

Additionally, there may be an indirect influence of German in the sense that the absence of animacy restrictions in German topic drop may have an influence on the semantic restrictions on null objects in EP. In this case, the bilingual speakers (in contrast to the other groups) would not show clear animacy restrictions in the use of null objects.

Hypothesis 3-Language-internal pathway: The bilingual speakers may show qualitative differences that are not necessarily related to their dominant language, German, but to a language-internal development. As shown above, the extension of object omissions along the referential hierarchy is a language-internal process that may affect natural languages, as it appears to be the case of the diachronic evolution of null objects in BP (Cyrino et al. 2000). The further extension of such a pathway by HSs of EP would be visible in a tendency to produce higher rates of animate objects than the other groups. Note that, in this case, animacy restrictions would exist, but would be relaxed in comparison to the other groups.

\section{$4 \quad$ Results}

\subsection{Type of object realization}

A total of 9920 transitive contexts were coded, in a first step, according to the type of object realization: DP, clause, wh-element and so-called 'pronominal contexts', which included demonstrative pronouns, accusative and dative clitics, and instances of object omission. After excluding the occurrences of clauses and wh-elements in object position, we analysed a total of 7597 tokens. Table 1 shows the total amount of DPs and pronominal contexts in raw counts. 
Table 1. Types of object realization in the four corpora (raw counts)

\begin{tabular}{lccccc}
\hline Type of object & G1_BIL & G2_BIL & G1_MON & G2_MON & Total \\
\hline DPs & 1319 & 1233 & 1334 & 1375 & 5261 \\
\hline Pronominal & 640 & 449 & 743 & 504 & 2336 \\
contexts & & & & & \\
\hline
\end{tabular}

First we intend to determine whether the four groups differ statistically with respect to the distribution of DPs and pronominal forms (including omissions). For this purpose, separate ANOVA were run, which show that the groups do not reveal significant differences regarding the use of DPs ( $p>0.05$ ), but they differ with regard to the distribution of pronominal forms $(\mathrm{F}(3)=7.4688)$. Therefore, in a second step, we concentrated only on the pronominal contexts. In 2336 utterances, the object was realized either as an accusative or dative clitic, as a demonstrative pronoun or a null element.

As described above, EP has three types of object omissions, i.e. VP ellipsis, unspecified objects and 'real' null objects. Table 2. shows the proportional distribution and the raw occurrences of null objects, unspecified objects and VP ellipsis.

Table 2. Distribution of null objects, unspecified objects and VP ellipsis

\begin{tabular}{lccccc}
\hline & G1_Bil & G2_Bil & G1_Mon & G2_Mon & total \\
\hline null objects & $35.9 \%(51)$ & $57.8 \%(89)$ & $58.2 \%(110)$ & $55.4 \%(98)$ & $52.6 \%(348)$ \\
\hline unspecified objects & $18.3 \%(26)$ & $21.4 \%(33)$ & $9 \%(17)$ & $17.5 \%(31)$ & $16.1 \%(107)$ \\
\hline VP ellipsis & $45.8 \%(65)$ & $20.8 \%(32)$ & $32.8 \%(62)$ & $27.1 \%(48)$ & $31.3 \%(207)$ \\
\hline Total (raw) & 142 & 154 & 189 & 177 & 662 \\
\hline
\end{tabular}


Table 2 shows that (only) 348 tokens of the whole corpus (out of 662 omissions) are null objects. The other tokens correspond to unspecified objects (16.1\%) and to VP ellipsis (31.3\%). Since only null objects compete syntactically and discursively with overt clitic pronouns, we further excluded the occurrences of VP ellipsis and unspecified objects and considered only null object structures for the quantitative and qualitative analysis. Table 3 shows the distribution of (accusative and dative) clitic pronouns, demonstratives and 'real' null objects per group in contexts with specific antecedents.

Table 3. Object realization in pronominal contexts in the four corpora (in \%)

\begin{tabular}{lcccc}
\hline & G1_BIL & G2_BIL & G1_MON & G2_MON \\
\hline clitic pronouns & $73.6 \%$ & $44.2 \%$ & $64.4 \%$ & $55.8 \%$ \\
\hline demonstratives & $11.6 \%$ & $22.8 \%$ & $11.4 \%$ & $14.6 \%$ \\
\hline null objects & $14.9 \%$ & $33.1 \%$ & $24.3 \%$ & $29.6 \%$ \\
\hline
\end{tabular}

A chi-squared test shows that, overall, the four groups reveal significant differences concerning the distribution of object realization in pronominal contexts $(\mathrm{X} 2(3)=$ 97.144; $\mathrm{p}<0.0001)$. With respect to the production of clitic pronouns, a further chisquared test reveals that the differences between all four groups are statistically significant $(\mathrm{p}<0.0001)$. The results demonstrate that the heritage bilingual speakers are the group with the lowest percentage of clitic realization (44.2\%). Conversely, the $1^{\text {st }}$ generation migrants present the highest rate of clitic production $(73.6 \%)$. Also the younger monolinguals in juxtaposition to the older generation produce less clitic pronouns (55.8\% against $64.4 \%$ ). However, the difference in the rates of clitic realization between the two monolingual groups is not sharp, compared with the migrant corpora.

As a consequence of the lower rate of clitic production in the HSs' corpus, this group presents the highest rate of demonstrative pronouns $(22.8 \%)$ and of null objects 
(33.1\%). A chi-squared test reveals that this group, in fact, differs significantly from the other three groups regarding the use of demonstrative pronouns $(\mathrm{p}<0.0001)$. Furthermore, the statistical results show that there are no statistically relevant differences between the other groups in this domain $(p=0.2496)$. As a matter of fact, the rate of demonstratives is similar in the older groups (G1_BIL: 11.6\%; G1_MON: $11.4 \%)$ and close to the corpus of the young monolingual speakers (14.6\%).

As for the distribution of null objects within the pronominal contexts, a chisquared test reveals that, globally, the four groups present statistical differences (X2 (3) $=8.782, \mathrm{p}<0.001$ ). The data show that the younger generations (both bilingual and monolingual) omit more objects than their older counterparts (migrants: $33.1 \%$ vs. $14.9 \%$; monolinguals $(29.6 \%$ vs $24.3 \%)$. This asymmetry is statistically significant between the two migrant groups, but not between the monolingual groups $(\mathrm{X} 2(1)=$ 2.9564, $\mathrm{p}=0.08554)$

So far, we have shown that HSs produce less clitic pronouns than the other groups and compensate this lower rate with a higher rate of demonstratives and null objects. Focusing, now, specifically on the distribution of null objects, in a further step, we analyzed their occurrence taking into account the syntactic contexts in which they are produced (island and sentence-initial omissions) and the semantic features [+/propositional] and [+/- animate].

\subsection{Syntactic aspects}

\subsubsection{Null objects in islands}

Two types of missing object contexts were coded for 'islands': VP ellipsis (see (22a)) and null object contexts (see (22b)). Table 4 shows the raw occurrences of missing objects in islands (due to the reduced number of occurrences we did not run a statistical analysis). 
(22) a. Raramente vejo. Quando vejo $\emptyset$ na televisão, só vejo animais.

$$
\text { when see1SG on TV [G2_mon_4] }
$$

'I barely see it. When I see it on TV, I just see animals.'

$(\varnothing=$ filmes / 'films')

b. Q. E fixas a palavra, anotas?

A. Sim, quando eu leio Ø muitas vezes e quero saber o que é.

$$
\text { when I read often [G2_bil_1] }
$$

'Q. Do you memorize the word? A. Sim, when I read it often and I want to know what it is.'

(

Table 4. Missing objects in island contexts (raw counts).

\begin{tabular}{lccccc}
\hline & G1_Bil & G2_Bil & G1_Mon & G2_Mon & Total \\
\hline null objects & 2 & 6 & 5 & 8 & 21 \\
\hline VP ellipsis & 4 & 4 & 6 & 5 & 19 \\
\hline Total & 6 & 10 & 11 & 13 & 40 \\
\hline
\end{tabular}

Contrary to what has been described in the literature, the data show the use of missing objects in VP ellipsis as well as in null object contexts within islands. This occurrence is attested not only in the bilingual but also in the monolingual corpora to the same extent. As for the type of island, we found examples of null elements in clefts (23a) and adverbial adjunct clauses (23b). Again, no group differences were found with regard to the type of island. 
(23) a. Q. Lembras-te se o avô teve dificuldades em encontrar trabalho para $t i ?$
A. Não, eu fui que procurei $\emptyset$.
[G1_bil_8]

me was who searched

'Q. Do you remember if grandpa had difficulties in finding work for you?

A. No, it was me who searched for it.'

$(\varnothing=$ trabalho / 'work')

b. Porque isto era uma freguesia muito rural.

Desde que eu comecei a conhecer $\emptyset$, apenas havia uma tasca na since that I started to know

freguesia.

[G1_mon_1]

'Because this was a very rural village. Ever since I first got to know it, there has only been one tavern in the village.'

$(\varnothing=\mathrm{a}$ freguesia / 'the village')

That (23a.) is indeed an island is illustrated by the impossibility of wh-extraction out of this kind of clause:

(24) $*\left[\begin{array}{ll}\mathrm{O} & \text { que }\end{array}\right]_{\mathrm{i}}$ é que eu fui que procurei $[-]_{\mathrm{i}}$ ?

the what is.it that I was that searched

Likewise, $w h$-movement is not allowed out of an adjunct clause such as (23b): 
(25) *[O que $]_{i}$ é que desde que eu comecei a conhecer $\emptyset_{\mathrm{i}}$, apenas the what is.it that since that I started to know, only havia uma tasca na freguesia? there.was one tavern in.the village.

\subsubsection{Sentence-initial object drop}

An extension of Germanic topic drop to Portuguese would be visible in sentences with VS order and a missing object (see 26):

(26) $[-] \mathrm{Vi}$ eu ontem.

[Top] saw I yesteraday

'I saw it yesterday."

Such a sentence would be target-like in Portuguese in contexts of VP-ellipsis with contrastive focus on the subject (27b). Otherwise, such constructions are not target-like.

(27) A. A Maria afinal não viu o filme. the Mary finally not saw the filme 'Mary finally didn't see the filme."

B. [-] Vi EU ontem. [TOP] saw I yesterday.

The results with respect to this construction are very clear. Neither the $1^{\text {st }}$ nor the $2^{\text {nd }}$ generation corpora contain $\varnothing \mathrm{VS}$-sentences that may resemble the Germanic topic drop structure.

\subsection{Semantic aspects}




\subsubsection{Propositional / non-propositional antecedents}

In this section we will take a closer look at the distribution of clitic and null pronouns according to the propositional / non-propositional status of the antecedent. Propositional null objects occur typically as objects of declarative or epistemic verbs (cf. ex. 28).

a. ... antes eu não sabia. [G2_bil_4]

before I not knew

'I didn't know this before.'

b. eu desconheço por acaso. Não sei... [G2_mon_3]

I not know by accident

'I happen not to know this.'

In order to identify the propositional/ non-propositional status, only $3^{\text {rd }}$ person accusative contexts were considered. The four corpora contain a total of 729 instances of $3^{\text {rd }}$ person accusatives. Table 5 shows the proportion of clitic / null pronouns per subcorpus, in propositional as well as non-propositional contexts.

Table 5. Object realization in [+ / - propositional] contexts in the four corpora (in \%)

\begin{tabular}{llcccc}
\hline & & G1_BIL & G2_BIL & G1_MON & G2_MON \\
\hline [- prop] & null obj & $46.85 \%$ & $76.06 \%$ & $50 \%$ & $63.6 \%$ \\
\cline { 2 - 6 } & clitic & $53.15 \%$ & $23.94 \%$ & $50 \%$ & $36.4 \%$ \\
\hline [+ prop] & null obj & $93.75 \%$ & $96.25 \%$ & $100 \%$ & $97.14 \%$ \\
\cline { 2 - 6 } & clitic & $6.25 \%$ & $3.75 \%$ & $0 \%$ & $2.86 \%$ \\
\hline
\end{tabular}

As expected, results reveal that all four groups show a very marked tendency to omit the accusative pronoun when referring to a proposition. The proportion of propositional 
null objects ranges from $93.75 \%$ (G1_BIL) to $100 \%$ (G1_MON). As for the objects referring to non-propositional antecedents, the distribution among null and clitic pronouns is very equilibrated in both $1^{\text {st }}$ generation groups (G1_MON: $50 \%$ null objects and clitics; G1_BIL: $46.85 \%$ null objects and $53.15 \%$ clitics). In the younger generation groups the proportion of null objects surpasses the rate of clitics in the non-propositional contexts. This tendency is even more visible in the $2^{\text {nd }}$ generation bilingual group (76.06\% of null objects) than in the $2^{\text {nd }}$ generation monolingual group (63.6\%). In order to test if the difference between the use of non-propositional object clitics vs. null objects is statistically significant, Wilcoxon signed-rank tests for related samples were applied for each group. The results reveal that, in fact, only in the younger generations, i.e. the HSs and the young monolinguals, there is a significant difference between the mean use of null and overt pronouns in non-propositional contexts (G2_BIL: $Z=-2,205$, $\left.p=.027 ; \mathrm{G} 2 \_\mathrm{MON}: Z=-2,197, p=.028\right)$.

\subsubsection{Animacy}

Regarding the factor 'animacy', example (29a) shows an animate and (29b), an inanimate null object. 
(29) a. E depois a minha mãe, foi também ela. Levou $\emptyset$ também pra cá.

brought $3 \mathrm{Sg}$ also to here

'And then my mother, she also went. (He) brought her also here.'

$(\varnothing=$ mãe / 'mother')

[G2_bil_8]

b. Ele [...] ia escavando aos bocadinhos a parede. [...].

Ia retirando Ø sempre aos bocadinhos. [G2_mon_1]

was removing always to.the bits

'He was digging out the wall, piece by piece. He was removing it piece by piece.

$(\varnothing=$ a parede / 'the wall')

Table 6 presents the rates of null objects with animate antecedents. Proportionally, the heritage bilinguals omit considerably more animate objects than the other groups (19.5\%, against G1_Bil: 4.1\%,G1_Mon: 9.4\%,G2_Mon: 6.6\%). All omitted pronouns are $3^{\text {rd }}$ person pronouns.

Table 6. Rate of animate null objects.

\begin{tabular}{lcccc}
\hline & G1_Bil & G2_Bil & G1_Mon & G2_Mon \\
\hline animate null objects & $4.1 \%$ & $19.5 \%$ & $9.4 \%$ & $6.6 \%$ \\
\hline
\end{tabular}

A chi-squared test reveals significant differences between the groups (X2 (3) = 15.529, $\mathrm{p}=0.001)$. Further chi-squared tests show that the HSs are indeed responsible for group differences (G1_BIL, G1_MON and G2_MON do not differ statistically, X2 (2) = $3.0225, \mathrm{p}=0.2206)$, i.e. HSs omit the object significantly more with animate objects than the other speaker groups. 
The rather reduced rates of animate null objects in the other groups confirms the results of Schwenter's (2014) study: inanimate direct object referents are significantly more likely to be null than definite animate anaphoric direct object referents. However, it has to be pointed out that even in the monolingual groups we find animate null objects, showing that this is not an outright ungrammatical construction in EP.

\section{Discussion and conclusion}

We start this discussion by analysing the distribution of missing objects in the four corpora. The results show that the second generation bilingual speakers do not differ from the other groups with respect to the type of object omissions employed. They produce all three types of omission structures (null objects, unspecified objects and VP ellipsis), with a higher proportion of null objects. This is in line with the distribution found in the monolingual corpora. Only the first generation migrants produce fewer null objects. This difference between the first and the second generation bilingual corpora shows that no characteristic of the speech of the second generation bilinguals can be traced back to ongoing changes already present in the speech of the first generation. These data also reveal that the bilingual speakers have successfully acquired missing object constructions in EP, which includes the null object, showing no incomplete knowledge of object realization / omission structures. Thus, no general acquisition deficit is visible, which is in line with previous studies on the acquisition of Portuguese as heritage language (Flores 2015; Flores et al. 2017; Rinke and Flores 2014).

There is also no sign of a deviant use of null objects in the bilingual group concerning the syntactic contexts in which the null object occurs. Null objects appear in islands in the speech of heritage bilinguals, but the occurrence of null objects in islands is not restricted to this group. This contradicts the idea of a general competence deficit of heritage speakers, since they do exactly the same as their monolingual peers.

Having discarded the hypothesis of an overall failure in acquiring null objects, we 
now want to explore the hypothesis that, in the case of HSs who are clearly dominant in German, the dominant language exerts influence on Portuguese, the less-used language. A scenario of cross-linguistic influence would be visible if heritage bilinguals would show a higher number of null objects in their speech than the other groups, but mostly in verb-initial sentences with post-verbal subjects, resembling German topic drop. Results, however, do not show this. Null objects do not occur in constructions which are parallel to the German topic-drop or 'pronoun zap' constructions. However, crosslinguistic influence could in principle also be rather indirect. More precisely, we cannot completely exclude that semantic restrictions are affected by language contact. Indirect language contact induced influence from Basque on null objects in contact Spanish is assumed by Gómez Seibane (2012). She proposes that this influence does not consist of direct incorporation of material from Basque into Spanish, as would be the case of sentence-initial object drop in our study, but of the elimination of semantic restrictions on existing null objects in Spanish. According to the author, intense contact between Basque and Spanish and the partial coincidence of constructions has led to a displacement of the null object to the left of the definiteness and animacy scale (Aissen 2003) from indefinite non-specific to definite and, although only marginally, from inanimate to animate and human. However, in the present case of German-Portuguese bilingualism, it is less likely that an extension of null objects along the animacy scale is due to language contact with German because of two reasons: first, the bilingual speakers still exhibit an animacy effect in the sense that they also prefer inanimate null objects over null animate objects; second, we also observe a certain extension along the referential scale in the case of the younger generation of monolinguals. This leads us to our preferred explanation: the idea of a language internal pathway.

In fact, the most revealing results are related to i) an overall higher proportion of null objects with non-propositional antecedents in the speech of both younger generations (bilingual and monolingual), which is more expressive in the bilingual 
group; and ii) a significant higher proportion of animate null objects in the speech of the bilingual group, even though also the other speaker groups omit animate $3^{\text {rd }}$ person pronouns to some extent. In our view, the fact that the two younger groups show a general higher proportion of null objects than the older generations and that they also opt more often for the null variant in non-propositional contexts may be interpreted in terms of generational change (Labov 1994) along the referential scale. The described advancement is more pronounced in the bilingual group because this group omits nonpropositional and animate objects significantly more often than the other populations. This relaxation of the referential scale seems to be a language-internal process that may affect natural languages, which is apparently independent of language contact, since it is not restricted to the bilingual group. If we adapt the representation proposed by Cyrino, Duarte and Kato (2000), the tendency observed in our data may be represented as in (30):

(30) Referential Hierarchy

\begin{tabular}{|c|c|c|c|}
\hline non-argument & propositional & $\begin{array}{l}\text { [-human] } \\
3 \text { p. }\end{array}$ & $\begin{array}{l}\text { [+human] } \\
3 \text { p. } 2 \text { p. } 1 \text { p. } \\
\text { +spec. }\end{array}$ \\
\hline
\end{tabular}

omissions in:

- first generation of EP monolingual/bilingual speakers

- $\quad$ second generation EP monolingual speakers

- EP bilingual heritage speakers

This advancement proceeds along this referential hierarchy. On the basis of this proposal, it is expected that an extension of null elements should universally proceed from [-referential] to [+referential] entities whereas the loss of null elements would proceed from [+referential] to [-referential]. 
One further result of the present study concerns the grammar of monolinguals and first generation migrants. Our data largely confirm Schwenter's (2014) results: inanimate anaphoric null objects are much more likely to occur than animate anaphoric null objects. This result, coupled with the finding that a null object may occur inside a strong island, is very much in line with the pattern observed in the case of Hebrew, another language with anaphoric null objects. Erteschik-Shir, Ibnari and Taube (2013) report a very similar animacy restriction on anaphoric null objects in Hebrew. Moreover, as in EP, the status of sentences with null objects in islands in Hebrew has been a matter of debate. Doron (1999) claims that such sentences are ungrammatical; Erteschik-Shir, Ibnari and Taube (2013), however, show that the null object may occur inside an island as long as the right context is provided. The authors argue in favor of a non-movement analysis of the gap. Our results support this view.

In conclusion, the present study shows that statements regarding the particularities of heritage languages must be formulated in a careful way. Widespread views of heritage speakers as incomplete language acquirers or as agents of language contact phenomena are favored explanations of heritage speakers' linguistic performance (Montrul 2016). However, linguistic outcomes that, on the surface, appear to be the consequence of language deficits or of cross-linguistic influence might, after closer inspection, be language-internal phenomena, that are part of the linguistic system and its natural development.

\section{References}

Aissen, Judith. 2003. Differential object marking: iconicity vs. economy. Natural Language and Linguistic Theory 21. 435-483.

Bayer, Josef, Markus Bader \& Michael Meng. 2001. Morphological underspecification meets oblique case: Syntactic and processing effects in German, Lingua 111. 465514. 
Camacho, José, Liliana Paredes \& Liliana Sánchez. 1997. Null objects in Andean bilingual Spanish. In Elisabeth Hughes, Mary Hughes \& Anne Greenhill (eds.), Proceedings of the Twenty First Annual Boston University Conference, 56-66. Sommerville/Mass.: Cascadilla Press.

Campos, Héctor. 1986. Indefinite object drop. Linguistic Inquiry 17(2). 354-359.

Castro, Tammer. 2016. Heritage and adult L2 acquisition of empty categories in a bidialectal \& bilingual context. Brazilian and European Portuguese in contact. Ph.D. Thesis, University of Tomsø.

Costa, João \& Inês Duarte. 2003. Objectos Nulos em Debate. In Ivo Castro \& Inês Duarte (eds.), Razões e Emoção. Miscelânea de Estudos em homenagem a Maria Helena Mira Mateus. Vol. I., 249-260. Lisbon: INCM.

Costa, João \& Maria Lobo. 2006. A aquisição de clíticos em PE: omissão de clíticos ou objecto nulo? In Fátima Oliveira \& Joaquim Barbosa (eds.), Textos Selecionados do XXI Encontro Nacional da Associação Portuguesa de Linguística, 285-293. Lisbon: APL.

Costa, João, Maria Lobo \& Carolina Silva. 2009. Null objects and early pragmatics in the acquisition of European Portuguese. Probus 21. 143-162.

Cyrino, Sônia M.L. 1993. Observações sobre a mudança diacrônica no português do Brasil: objeto nulo e clíticos. In Ian Roberts \& Mary Kato (eds.), Português brasileiro, uma viagem diacrônica, 163-184. Campinas : Ed. UNICAMP.

Cyrino, Sônia M.L. 1997. O objeto nulo no português do Brasil - um estudo sintático diacrônico. Londrina: Editora da UEL.

Cyrino, Sônia M.L., Maria Eugênia Duarte \& Mary A. Kato. 2000. Visible subjects and invisible clitics in Brazilian Portuguese. In Mary A. Kato \& Esmeralda V. Negrão (eds.), Brazilian Portuguese and the Null Subject Parameter, 55-73. Frankfurt am Main, Vervuert/ Madrid: Iberoamericana.

Cyrino, Sônia M.L. \& Matos, Gabriela. 2016. Null Objects and VP Ellipsis in European 
and Brazilian Portuguese. In W. Leo Wetzels, Sergio Menuzzi \& João Costa (eds.), The Handbook of Portuguese Linguistics, 294-317. Malden: WileyBlackwell.

Doron, Edit. 1999. V-movement and VP-ellipsis. In Shalom Lappin \& Elabbas Benmamoun (eds.), Fragments: Studies in Ellipsis and Gapping, 124-140. Oxford: Oxford University Press.

Duarte, Maria Eugênia L. 1986. Variação e Sintaxe: clítico acusativo, pronome lexical e categoria vazia no português do Brasil. M.A. Thesis, São Paulo: PUC.

Duarte, Inês \& João Costa. 2013. Objecto nulo. In Eduardo P. Raposo et al. (eds.), Gramática do português (vol. II), 2339-2348. Lisbon: Gulbenkian.

Erteschik-Shir, Nomi, Lena Ibnari, \& Sharon Taube. 2013. Missing objects as topic drop. Lingua 136. 145-169.

Farrell, Patrick. 1990. Null objects in Brazilian Portuguese. Natural Language and Linguistic Theory 8 (3). 325-346.

Flores, Cristina. 2012. Differential effects of language attrition in the domains of verb placement and object expression. Bilingualism. Language and Cognition 15(3). $550-567$.

Flores, Cristina. 2015. Understanding heritage language acquisition. Some contributions from the research on heritage speakers of European Portuguese. Lingua 164. $251-265$.

Flores, Cristina, Esther Rinke \& Cecília Azevedo. 2017. Object realization across generations. A closer look on the spontaneous speech of Portuguese first and second generation migrants. In Elisa Domenico (ed.), Complexity in Acquisition, 179-206. Cambridge: Cambridge Scholars.

Franco, Jon \& Alazne Landa. 2003. Null objects revisited. In Rafael Núñez-Cedeño, Luis López \& Richard Cameron (eds.), A Romance Perspective on Language 
Knowledge and Use, Selected Papers from the $31^{\text {st }}$ Linguistic Symposium in Romance Languages (LSRL), 311 - 326. Amsterdam/Philadelphia: Benjamins.

Giannakidou, Anastasia \& Jason Merchant. 1997. On the interpretation of null indefinite objects in Greek. Studies in Greek Linguistics 17. 141-155.

Gribanova, Vera. 2013. Verb-Stranding Verb Phrase Ellipsis and the Structure of the Russian Verbal Complex. Natural Language and Linguistic Theory 31. 91-136.

Gómez Seibane, Sara. 2013. La omisión y duplicación de objetos en el castellano del País Vasco. In Bruno Camus Bergereche \& Sara Gómez Seibane (eds.), El castellano del País Vasco, 193-214. Bilbao: Universidad del País Vasco.

Holmberg, Anders. 2001. The Syntax of Yes and No in Finnish. Studia Linguistica 55 (2). 140-174.

Huang, C-T. James. 1984. On the Distribution and Reference of Empty Pronouns. Linguistic Inquiry 15. 531-574.

Kato, Mary A., Maria Eugênia Duarte, Sônia Cyrino, S. \& Rosane de A. Berlinck. 2006. Português brasileiro no fim do século XIX e na virada do milênio. In Suzana Cardoso, Jacyra Mota \& Rosa Virgínia Matto e Silva (eds.), Quinhentos anos de história lingüística no Brasil, 413-438. Salvador, Empresa Gráfica da Bahia/Funcultura/Governo da Bahia.

Kato, Mary A. \& Eduardo P. Raposo. 2005. Obje(c)tos e artigos nulos: similaridades e diferenças entre o português europeu e o português brasileiro. In Maria Denilda Moura (eds.), Reflexões sobre a sintaxe do português, 73-96. Maceió: Edufal.

Kato, Mary. 1993. The distribution of pronouns and null elements in object position in Brazilian Portuguese. In William J. Ashby, Marianne Mithun \& Giorgio Perissinotto (eds.), Linguistic perspectives on the Romance Languages. Selected Papers from the XXI Linguistic Symposium on Romance Languages Santa Barbara, February 21-24, 1991 (Current Issues in Linguistic Theory Series), 225235. Amsterdam: John Benjamins. 
Kupisch, Tanja \& Jason Rothman. 2016. Terminology matters! Why difference is not incompleteness and how early child bilinguals are heritage speakers. International Journal of Bilingualism. OnlineFirst doi:10.1177/1367006916654355

Labov, William. 1963. The social motivation of a sound change. Word 19. 273-309.

Labov, William. 1994. Principles of linguistic change. Volume 1: Internal factors. Oxford: Blackwell.

Leonetti, Manuel. 2008. Specificity in clitic doubling and in differential object marking. Probus 20. 33-66.

Landa, Alazne. 1995. Conditions on null objects in Basque Spanish and their relation to "Leísmo" and Clitic Doubling. Doctoral Thesis, University of Southern California.

Meisel, Jürgen. 2001. The simultaneous acquisition of two first languages: Early differentiation and subsequent development of grammars. In Jasone Cenoz \& Fred Genesee (eds.), Trends in bilingual acquisition, 11 - 41. Amsterdam: John Benjamins.

Montrul, Silvina. 2008. Incomplete acquisition in bilingualism: Re-examining the age factor. Amsterdam: John Benjamins.

Montrul, Silvina. 2016. The acquisition of heritage languages. Cambridge: Cambridge University Press.

Müller, Natascha \& Aafke Hulk. 2001. Crosslinguistic influence in bilingual children: object omissions and root infinitives. In S. Catherine Howell, Sarah A. Fish \& Thea Keith-Lucas (eds.), Proceedings of the 24th Annual Boston University Conference on Child Language Development, 546-557. Sommerville, M.A. Cascadilla Press.

Pérez-Leroux, Ana Teresa, Mihaela Pirvulescu, Yves Roberge, Danielle Thomas \& Lyn Tieu. 2006. Variable input and object drop in child language. In C. Gurski and M. Radisic (eds.), Proceedings of the Canadian Linguistics Association Conference, 
westernlinguistics.ca/Publications/CLA2006/Perez-Leroux_etal.pdf. (retrieved July 15, 2015)

Pirvulescu, Mihaela, Ana-Teresa Pérez-Leroux, Yves Roberge, Strik Nelleke \& Danielle Thomas. 2014. Bilingual effects: Exploring object omission in pronominal languages. Bilingualism: Language and Cognition 17(3). 495-510.

Raposo, Eduardo P.1986. On the null object construction in European Portuguese. In Osvaldo Jaeggli, \& Carmen Silva-Corvalán (eds.). Studies in Romance Linguistics, 373-390. Dordrecht: Foris.

Raposo, Eduardo P. 2004. Objetos nulos e CLLD. Uma teoria unificada. Revista da ABRALIN 3(1-2). 41-73.

Raposo, Eduardo P. \& Juan Uriagereka. 1996. Indefinite SE. Natural Language and Linguistic Theory 14. 749-810.

Rizzi, Luigi. 1986. Null objects in Italian and the theory of pro. Linguistic Inquiry 17. $501-558$.

Ross, John Robert. 1982. Pronoun deleting processes in German. Paper presented at the Annual Meeting of the Linguistic Society of America, San Diego, CA.

Rothman, Jason \& Jeanine Treffers-Daller. 2014. A prolegomenon to the construct of the native speaker: heritage speaker bilinguals are natives too! Applied Linguistics 35(1). 93-98.

Sánchez, Liliana. 1999. Null objects and D0 features in contact varieties of Spanish. In Jean-Marc Authier, Barbara E. Bullock \& Lisa A. Reed (eds.), Formal Perspectives on Romance Linguistics. Selected papers from the 28th Linguistic Symposium on Romance Languages (LSRL XXVIII), 227 - 242. Amsterdam / Philadelphia: Benjamins.

Schwenter, Scott A. 2014. Two kinds of Differential Object Marking in Portuguese and Spanish. In Patrícia Amaral \& Ana Maria Carvalho (eds.), Portuguese/Spanish interfaces, 237-260. Amsterdam: Benjamins. 
Silva-Corvalán, Carmen. 1994. Language contact and change: Spanish in Los Angeles. Oxford: Clarendon.

Silverstein, Michael. 1976. Hierarchy of Features and Ergativity. In Robert M.W. Dixon (ed.), Grammatical Categories in Australian Languages, 112-171. Canberra: Australian National University.

Suñer, Margarida \& María Yépez. 1988. Null definite objects in Quiteño. Linguistic Inquiry 19 (3). 511-519.

Trifonas, Peter Pericles \& Themistoklis Aravossitas. eds. 2017. International Handbook on Research and Practice in Heritage Language Education. Springer International Publishing AG.Uriagereka, Juan. 1995. Aspects of the syntax of clitic placement in Western Romance. Linguistic Inquiry 26. 79-123.

Yépez, María. 1986. Direct Object Clitics in Quiteño Spanish, M.A. thesis, Cornell University, Ithaka, New York. 